\title{
Shading effect on microclimate and thermal comfort indexes in integrated crop-livestock-forest systems in the Brazilian Midwest
}

\author{
Nivaldo Karvatte Jr. ${ }^{1}$ Elcio Silvério Klosowski ${ }^{2}$ Roberto Giolo de Almeida ${ }^{3}$. \\ Eduardo Eustáquio Mesquita ${ }^{2}$. Caroline Carvalho de Oliveira ${ }^{4} \cdot$ Fabiana Villa Alves $^{3}$
}

Received: 1 June 2015 /Revised: 18 April 2016 / Accepted: 26 April 2016/Published online: 14 May 2016

(C) ISB 2016

\begin{abstract}
The objective of this paper was to perform a microclimate evaluation and determine the indexes of thermal comfort indexes, in sun and shade, in integrated croplivestock-forest systems with different arrangements of eucalyptus and native trees, in the Brazilian Midwest. The experiment was conducted at Embrapa Beef Cattle in Campo Grande, state of Mato Grosso do Sul, Brazil, from July to September 2013. The evaluations were conducted on four consecutive days, from 8:00 a.m. to 5:00 p.m., local time (GMT $-4: 00$ ), with 1 hour intervals, recording the microclimate parameters: air temperature $\left({ }^{\circ} \mathrm{C}\right)$, black globe temperature $\left({ }^{\circ} \mathrm{C}\right)$, wet bulb temperature $\left({ }^{\circ} \mathrm{C}\right)$, relative humidity $(\%)$, and wind speed $\left(\mathrm{m} \cdot \mathrm{s}^{-1}\right)$, for the subsequent calculation of the Temperature and Humidity Index, the Black Globe Temperature and Humidity Index, and the Radiant Thermal Load. The largest changes in microclimate parameters were found in the full sun, between 12:00 p.m. and 1:00 p.m., in less dense eucalyptus system, followed by the scattered native trees system, resulting in a maximum Temperature and Humidity Index of 81, Black Globe Temperature and Humidity Index of 88 and Radiant Thermal Load of $794 \mathrm{~W} \mathrm{~m}^{-2}$. Therefore, it is observed that with the presence
\end{abstract}

Nivaldo Karvatte, Jr.

nivaldok@gmail.com

1 State University of West Paraná, UNIOESTE, Marechal Cândido Rondon, State of Paraná, Brazil

2 Department of Animal Science, UNIOESTE, Marechal Cândido Rondon, State of Paraná, Brazil

3 Embrapa Beef Cattle, Campo Grande, State of Mato Grosso do Sul, Brazil

4 UFVJM, Federal University of Jequitinhonha and Mucuri Valleys, Diamantina, State of Minas Gerais, Brazil of trees in pastures were possible reductions of up to $3.7 \%$ in Temperature and Humidity Index, $10.2 \%$ in the Black Globe Temperature and Humidity Index, and $28.3 \%$ of the Radiant Thermal Load in the shade. Thus, one can conclude that the presence of trees and their arrangement in the systems provide better microclimate conditions and animal thermal comfort in pastures.

Keywords Ambience $\cdot$ Animal welfare $\cdot$ Eucalyptus $\cdot$ Native trees $\cdot$ Shading $\cdot$ Thermal stress

\section{Introduction}

Having second largest herd in the country, the Brazilian state of Mato Grosso do Sul is a world reference in the agricultural sector, with approximately 21 million hectares of planted pastures, 8.5 million animals slaughtered/year and revenues of US\$ 312 million in exports of fresh beef (IBGE 2015). The state is also characterized by its territory; about $60 \%$ is located within the Cerrado biome, tropical climate with dry winter and high temperatures all year round. In these regions, grazing animals are constantly exposed to direct solar radiation, causing stress and physiological dysfunction compromising the welfare and productivity due to excessive production of heat for the control of homeothermy (Aggarwal and Upadhyay 2013; Tripon et al. 2014).

In extensive production systems, the selection of more adapted breeds to climate effects associated with the supply of shade has become efficient management strategies against climate effects on animals. The shadow in adequate amounts helps to reduce the heat load associated with direct solar radiation, reducing the temperature of the air and promoting increased humidity in the shadow cast by trees and improving animal welfare. 
Thus, in recent years, the integrated crop-livestock-forest systems, although initially designed for the recovery of soils and degraded pastures, have also excelled by improving the microclimate conditions, mitigating the heat through trees and contributing to the sustainability of livestock farming in the tropics with direct effect on the welfare and thermal comfort (Broom et al. 2013).

However, it is a mistake to consider the uniqueness of quantitative and qualitative characteristics of natural shading, particularly in integration systems, as the efficiency of the understory microclimate modification is linked mainly to the morphological characteristics of the tree species used as well as to its density (Schumacher and Poggiani 1993; Silva and Maia 2013).

The objective of the research was to evaluate the microclimate and determine the thermal comfort indexes, in sun and shade, in integrated systems with different arrangements of eucalyptus and native trees in the Brazilian Midwest.

\section{Materials and methods}

\section{Location and climate pattern}

The experiment took place at the Brazilian Agricultural Research Corporation-Embrapa Beef Cattle, located in Campo Grande, state of Mato Grosso do Sul, Brazil, at $20^{\circ}$ $27^{\prime}$ south latitude, $54^{\circ} 37^{\prime}$ west longitude, and $530 \mathrm{~m}$ above sea level. According to Köppen's (1948) classification, the weather pattern in the region is in the transition zone between warm temperate (CFA) and tropical wet (Aw) climates, with rainfalls and average annual temperatures of $1560 \mathrm{~mm}$ and $23{ }^{\circ} \mathrm{C}$, respectively.

\section{Experimental area}

The experimental area, with $18 \mathrm{ha}^{-1}$, consists of three integrated systems, so that each system is subdivided in four paddocks with $1.5 \mathrm{ha}^{-1}$, established in 2008 with Piatã grass (Brachiaria brizantha cv. BRS Piata), as follows: (i) integrated croplivestock-forest system 1 (ICLF-1) with $14 \mathrm{~m}$ between tree rows and a density of 357 trees $/ \mathrm{ha}^{-1}$; (ii) integrated croplivestock-forest system 2 (ICLF-2), with $22 \mathrm{~m}$ between tree rows and a density of 227 trees $/ \mathrm{ha}^{-1}$; and (iii) integrated croplivestock-forest system 3 (ICLF-3), with five scattered native Cerrado trees $/ \mathrm{ha}^{-1}$. The tree component of ICLF-1 and ICLF-2 is eucalyptus (Eucalyptus grandis x E. urophylla clone H 13), with a $2 \mathrm{~m}$ space between trees, an average height of $26 \mathrm{~m}$ in August 2013, and pruned up to $6 \mathrm{~m}$ high. From the three species present in ICLF-3, two were chosen for evaluation due to its greatest occurrence: Cambará (Gochnatia polymorpha Less.) and Cumbaru (Dipteryx alata Vog).

\section{Microclimate records}

To avoid weather variations between systems, were evaluated, simultaneously, one paddock of each system per day, in four consecutive days (corresponding to the total number of paddocks by system), preferably sunny days, in the months of July, August, and September 2013 (dry winter season). Data were recorded from 8:00 a.m. to 5:00 p.m. local time (GMT04:00), in hourly intervals between evaluations, according to Guiselini et al. (1999) and Gurgel et al. (2012). To determine the air temperature $\left({ }^{\circ} \mathrm{C}\right)$ and relative humidity $(\%)$, digital datalogger thermo-hygrometers (Instrutherm ${ }^{\circledR}$, HT-500) (humidity 0.0 to $100.0 \%$ scale; $3 \%$ precision, and $0.1 \%$ resolution; and temperature -40.0 to $70.0{ }^{\circ} \mathrm{C}$ scale; -20.0 to $50.0^{\circ} \mathrm{C}$ precision, and $0.1^{\circ} \mathrm{C}$ resolution) were inserted into perforated PVC pipes (with $0.15 \mathrm{~m}$ lengths, $0.40 \mathrm{~m}$ diameter, with 12 holes drilled around the pipe), as described by Trumbo et al. (2012). The wet bulb temperatures $\left({ }^{\circ} \mathrm{C}\right)$ were obtained from a psychrometric visual reading set (Incoterm $®$, with a -10.0 to $+50.0^{\circ} \mathrm{C}$ scale). To measure the black globe temperature $\left({ }^{\circ} \mathrm{C}\right)$, the adopted methodology was that proposed by Souza et al. (2002), using digital datalogger thermo-hygrometers (Instrutherm ${ }^{\circledR}$, HT-500) inserted into dim black plastic floats (PVC) with $0.15 \mathrm{~m}$ diameter. The wind speed $\left(\mathrm{m} \mathrm{s}^{-1}\right)$ was measured with a portable digital anemometer (Homis ${ }^{\circledR}$, HMM 489; 0.4 to $30.0 \mathrm{~m} \mathrm{~s}^{-1}$ scale; $>20.0 \mathrm{~m} \mathrm{~s}^{-1}$ precision; $0.1 \mathrm{~m} \mathrm{~s}^{-1}$ resolution) for $3 \mathrm{~min}$ with the devices' sensors facing the wind direction.

The pieces of equipment were placed in full sun (A) and in the shadow cast by trees (B), in two replications for $2.0 \mathrm{~m}$ from the tree lines and $1.3 \mathrm{~m}$ above the ground (corresponding to the height of the mass center of adult beef cattle) (Fig. 1), horizontally displaced according to the shadow cast by trees and the zenith angle variation. For fixation, in systems with eucalyptus (a; ICLF-1 and ICLF-2), in each paddock it has been extended two raffia ribbons between two rows of trees, where the equipments already calibrated and programmed were fixed. In the area with scattered native trees (b; ICLF3 ), they were allocated in cages exclusion, to form a support structure at the desired height $(1.3 \mathrm{~m})$. At the end of each day evaluation, the equipments were relocated to the subsequent paddock.

The meteorological data from the experimental environment were collected daily by a weather station (A702INMET), $3 \mathrm{~km}$ distance from the experimental area.

\section{Thermal comfort indexes}

The thermal comfort indexes, recommended by Guiselini et al. (1999); Gurgel et al. (2012); Navarini et al. (2009), and Silva and Maia (2013), were calculated for each time and place (shade and full sun), for the 3 months of evaluation, and for the three integrated systems. 
Fig. 1 Schematic representation for fixation of equipment, in a integrated crop-livestock, forest systems, with eucalyptus (ICLF-1 and ICLF-2), and $\mathbf{b}$ integrated crop-livestock-forest system, with scattered native trees (ICLF-3). Allocated in full sun $(\mathrm{A})$ and in tree casts shadows (B), with two replications
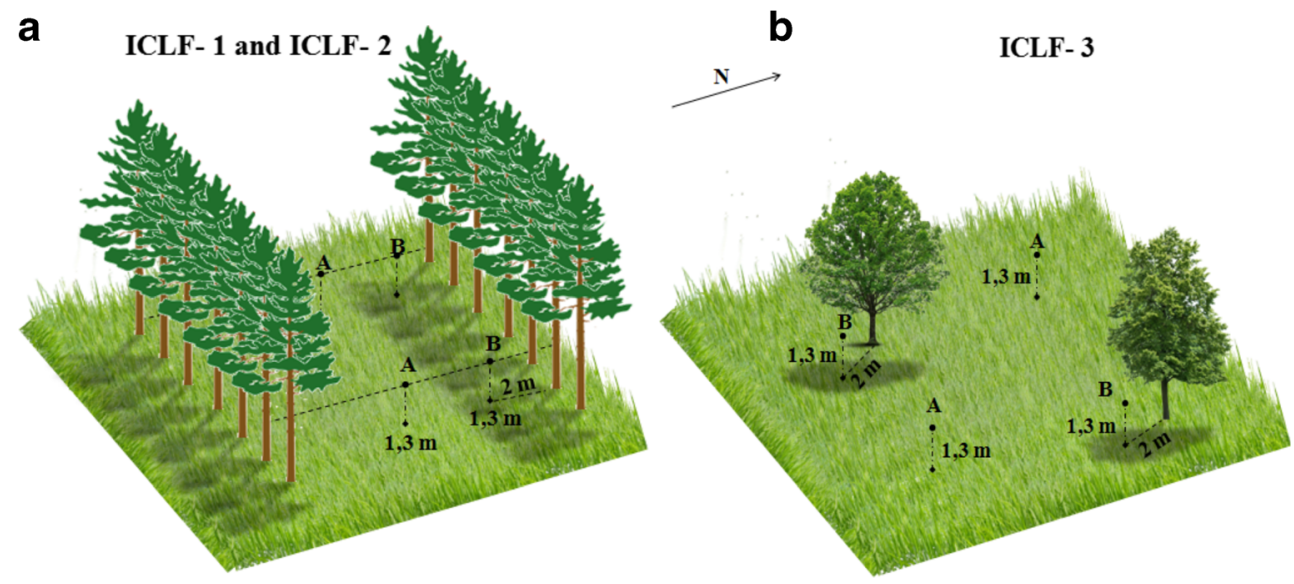

The Temperature and Humidity Index (Thom 1958) was determined by Eq. (1):

$\mathrm{THI}=\mathrm{DBT}+0.36 \mathrm{WBT}+41.5$

where:

THI - Temperature and Humidity Index, dimensionless

DBT - dry-bulb temperature, ${ }^{\circ} \mathrm{C}$; and,

WBT - wet bulb temperature, ${ }^{\circ} \mathrm{C}$.

The Black Globe Temperature and Humidity Index (Buffington et al. 1981), was estimated according to Eq. (2):

$\mathrm{BGHI}=\mathrm{TBG}+0.36 \mathrm{WBT}+41.5$

where:

BGHI - Black Globe Temperature and Humidity Index, dimensionless

TBG - black globe temperature, ${ }^{\circ} \mathrm{C}$; and,

WBT - wet bulb temperature, ${ }^{\circ} \mathrm{C}$.

Equation (3), proposed by Esmay (1979), was used to determine the radiant thermal load:

$$
\mathrm{RTL}=\boldsymbol{\sigma}(\mathrm{MRT})^{4}
$$

where:

RTL - Radiant Thermal Load, $\mathrm{Wm}^{-2}$; $\sigma$ - Stefan-Boltzmann constant 5,67.10 ${ }^{-8} \mathrm{~K}^{-4}$; and MRT - mean radiant temperature, $\mathrm{K}$.

$$
\mathrm{MRT}=100 \sqrt[4]{ }\left(2.51 \sqrt{\mathrm{Ws}}(\mathrm{TBG}-\mathrm{DBT})+\left(\frac{\mathrm{TBG}}{100}\right)^{4}\right)
$$

where:

Ws - wind speed, $\mathrm{m} \mathrm{s}^{-1}$;

TBG - black globe temperature, ${ }^{\circ} \mathrm{C}$;

DBT - dry-bulb temperature, ${ }^{\circ} \mathrm{C}$.

\section{Experimental design and statistical analysis}

The experimental design was randomized block (months: July, August, and September) arranged in a split-split-splitplot scheme, with four replications (corresponding to paddocks). The split-plots corresponded to integrated systems (ICLF-1, ICLF-2, and ICLF-3), split-split-plots to places (shade and sun), and split-split-split-plots to schedules (from 8:00 a.m. to 5:00 p.m.), with the following mathematical model:

$$
\begin{aligned}
\mathrm{Y}_{\mathrm{ijklm}}= & \mu+\mathrm{M}_{\mathrm{i}}+\mathrm{e}_{\mathrm{ij}}+\mathrm{S}_{\mathrm{k}}+\mathrm{MS}_{\mathrm{ik}}+\mathrm{e}_{\mathrm{ijk}}+\mathrm{P}_{\mathrm{l}}+\mathrm{MP}_{\mathrm{il}} \\
& +\mathrm{SP}_{\mathrm{kl}}+\mathrm{MSP}_{\mathrm{ikl}}+\mathrm{e}_{\mathrm{ijkl}}+\mathrm{H}_{\mathrm{m}}+\mathrm{MH}_{\mathrm{im}}+\mathrm{PH}_{\mathrm{lm}} \\
& +\mathrm{SH}_{\mathrm{km}}+\mathrm{MPH}_{\mathrm{ilm}}+\mathrm{MSH}_{\mathrm{ikm}}+\mathrm{SPH}_{\mathrm{klm}} \\
& +\mathrm{MSPH}_{\mathrm{iklm}}+\mathrm{e}_{\mathrm{ijklm}}
\end{aligned}
$$

$\mathrm{Y}_{\mathrm{ijklm}}$ : response variable; $\mu$ : overall mean; $\mathrm{M}_{\mathrm{i}}$ : effect of the month; $\mathrm{e}_{\mathrm{ij}}$ : error (a); $\mathrm{S}_{\mathrm{k}}$ : effect of the systems; $\mathrm{MS}_{\mathrm{ik}}$ : interaction effect of month $\times$ systems; $\mathrm{e}_{\mathrm{ijk}}$ : error (b); $\mathrm{P}_{1}$ : effect of the place; $\mathrm{MP}_{\mathrm{i} 1}$ : interaction effect of month $\times$ place; $\mathrm{SP}_{\mathrm{k} 1}$ : interaction effect of systems $\times$ place; $\mathrm{MSP}_{\mathrm{ik} 1}$ : interaction effect of months $\times$ systems $\times$ place; $\mathrm{e}_{\mathrm{ijk}}$ : error $(\mathrm{c}) ; \mathrm{H}_{\mathrm{m}}$ : effect of the hour; $\mathrm{MH}_{\mathrm{im}}$ interaction effect of month $\times$ hour; $\mathrm{PH}_{\mathrm{lm}}$ : interaction effect of place $\times$ hour; $\mathrm{SH}_{\mathrm{km}}$ : interaction effect of systems $\times$ hour; $\mathrm{MPH}_{\mathrm{ilm}}$ : interaction effect of month $\times$ place $\times$ hour; $\mathrm{MSH}_{\mathrm{ikm}}$ : interaction effect of month $\times$ systems $\times$ hour; $\mathrm{SPH}_{\mathrm{klm}}$ : interaction effect of systems $\times$ place $\times$ hour; $\mathrm{MSPH}_{\mathrm{iklm}}$ : interaction effect of month $\times$ systems $\times$ place $\times$ hour; $e_{i j k l m}$ : error $(d)$.

Data were submitted to analysis of variance (ANOVA) and regression through the statistical application SAS 9.0 (2002), adopting a $5 \%$ level of probability. 
Fig. 2 Climate monthly average in the experimental environment (*months of evaluation). Records collected daily by weather station (A702-INMET)

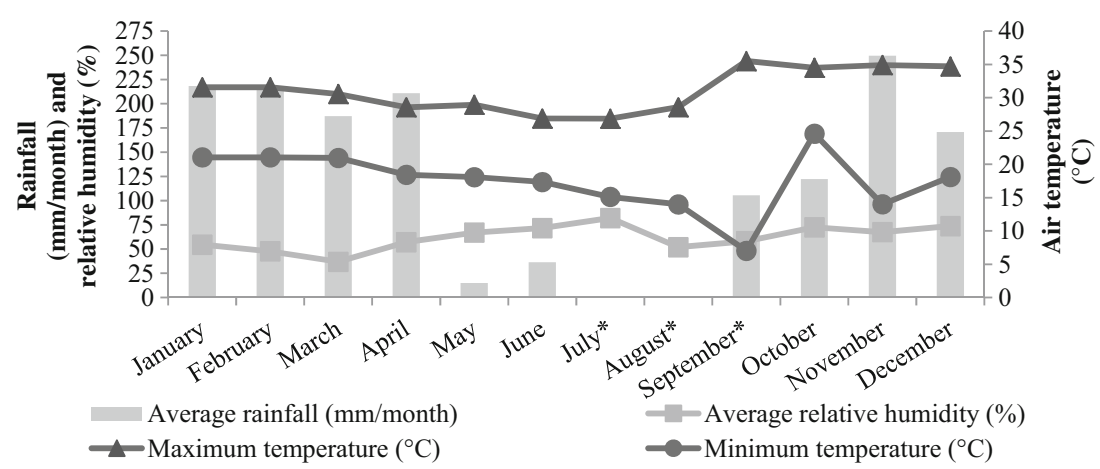

\section{Results}

\section{Microclimate variables}

Figure 2 shows the climate monthly average in the experimental area throughout year 2013. The months of July, August, and September (data collection period) were characterized by high temperatures, medium to low air humidity and lack of rain, mainly in July and August.

Thereby, the largest air temperature and black globe temperature values were observed in the month of September, in the sun, between 12:00 a.m. and 1:00 p.m. in all production systems (Table 1). The system with scattered native trees (ICLF-3) showed the highest average of air temperature $\left(43.5^{\circ} \mathrm{C}\right)$ and black globe temperature $\left(48.2^{\circ} \mathrm{C}\right)$, followed by system with dense eucalyptus (ICLF-1), with an air temperature of $39.4{ }^{\circ} \mathrm{C}$ and black globe temperature of $48.3{ }^{\circ} \mathrm{C}$, and system less dense eucalyptus (ICLF-2), with an air temperature of $37.8^{\circ} \mathrm{C}$ and black globe temperature of $42.9{ }^{\circ} \mathrm{C}$. Such microclimate parameters showed significant reductions in the shade, thus the ICLF-1 system, with dense eucalyptus, showed lower air temperature $\left(33.6{ }^{\circ} \mathrm{C}\right)$ and black globe temperature $\left(34.8^{\circ} \mathrm{C}\right)$, followed by ICLF-3 system, with scattered native trees with $34.6{ }^{\circ} \mathrm{C}$ for air temperature and $35.7{ }^{\circ} \mathrm{C}$ for black globe temperature, and ICLF-2 system, with less dense eucalyptus with $35.1{ }^{\circ} \mathrm{C}$ air temperature and $35.9^{\circ} \mathrm{C}$ black globe temperature. Therefore, it is clear that there has been chronic exposure of animals to high temperatures (Morais et al. 2008).

The lower relative humidity values were recorded at the same time interval (12:00 p.m. to 1:00 p.m.), in the sun, with rates of $15.2,18.9$, and $20.4 \%$ for ICLF-3, ICLF-1, and ICLF-2 systems, respectively (Table 2). It should be emphasized that a higher relative humidity occurred in the dense eucalyptus system (ICLF-1). For

Table 1 Month average of air temperature $\left(\mathrm{Ta},{ }^{\circ} \mathrm{C}\right)$, black globe temperature $\left(\mathrm{Tbg},{ }^{\circ} \mathrm{C}\right)$, in sun and shade, in integrated crop-livestock-forest systems containing eucalyptus (ICLF-1and ICLF-2) and native trees (ICLF-3), in Campo Grande, MS, Brazil

\begin{tabular}{|c|c|c|c|c|c|c|c|c|c|c|c|c|c|c|c|c|c|c|c|c|c|c|}
\hline \multirow[t]{3}{*}{ Systems } & \multirow[t]{3}{*}{ Months } & \multirow[t]{3}{*}{ Place } & \multicolumn{10}{|c|}{$\mathrm{Ta}\left({ }^{\circ} \mathrm{C}\right)$} & \multicolumn{10}{|c|}{$\operatorname{Tbg}\left({ }^{\circ} \mathrm{C}\right)$} \\
\hline & & & \multicolumn{10}{|c|}{ Hours } & \multicolumn{10}{|c|}{ Hours } \\
\hline & & & 8 & 9 & 10 & 11 & 12 & 1 & 2 & 3 & 4 & 5 & 8 & 9 & 10 & 11 & 12 & 1 & 2 & 3 & 4 & 5 \\
\hline \multirow[t]{6}{*}{ ICLF-1 } & \multirow[t]{2}{*}{ July } & Sun & 21.0 & 20.2 & 20.6 & 22.2 & 22.7 & 23.7 & 23.6 & 22.5 & 21.6 & 19.3 & 24.0 & 23.5 & 23.0 & 25.3 & 25.6 & 27.1 & 26.2 & 24.1 & 22.7 & 19.1 \\
\hline & & Shade & 20.0 & 19.5 & 20.0 & 21.4 & 22.1 & 22.7 & 22.8 & 22.2 & 21.5 & 19.8 & 20.5 & 20.6 & 21.2 & 23.0 & 23.7 & 24.4 & 24.2 & 23.1 & 21.9 & 19.7 \\
\hline & \multirow[t]{2}{*}{ August } & Sun & 33.7 & 36.3 & 37.4 & 37.5 & 38.3 & 37.6 & 36.1 & 31.0 & 23.1 & 19.3 & 41.3 & 43.4 & 46.0 & 46.1 & 47.1 & 47.5 & 43.6 & 41.9 & 27.7 & 19.6 \\
\hline & & Shade & 26.9 & 29.9 & 31.5 & 32.7 & 31.9 & 31.8 & 31.2 & 30.6 & 25.4 & 21.0 & 28.0 & 35.8 & 32.0 & 35.2 & 32.6 & 33.0 & 32.2 & 31.6 & 25.0 & 21.0 \\
\hline & \multirow[t]{2}{*}{ September } & Sun & 32.9 & 34.0 & 35.7 & 37.4 & 38.7 & 39.4 & 38.1 & 36.9 & 28.8 & 25.1 & 37.8 & 41.5 & 44.0 & 46.8 & 48.3 & 47.3 & 43.7 & 41.4 & 35.0 & 26.0 \\
\hline & & Shade & 29.3 & 32.3 & 32.8 & 33.6 & 33.6 & 33.7 & 33.8 & 33.0 & 30.1 & 28.3 & 32.2 & 33.9 & 34.8 & 35.4 & 34.8 & 35.0 & 36.4 & 31.3 & 27.8 & 26.2 \\
\hline \multirow[t]{6}{*}{ ICLF-2 } & \multirow[t]{2}{*}{ July } & Sun & 19.1 & 19.5 & 20.3 & 21.7 & 22.5 & 23.2 & 23.2 & 22.2 & 21.0 & 19.4 & 19.8 & 21.0 & 21.9 & 23.8 & 24.5 & 25.7 & 25.2 & 23.4 & 21.4 & 19.1 \\
\hline & & Shade & 19.2 & 19.5 & 20.3 & 21.8 & 22.4 & 22.9 & 23.0 & 22.1 & 21.1 & 19.5 & 20.2 & 21.1 & 21.8 & 23.6 & 24.1 & 24.9 & 24.5 & 23.0 & 21.5 & 19.5 \\
\hline & \multirow[t]{2}{*}{ August } & Sun & 27.9 & 30.7 & 35.2 & 35.3 & 36.6 & 35.2 & 34.0 & 31.1 & 26.9 & 23.0 & 29.2 & 32.5 & 41.8 & 43.5 & 42.2 & 39.7 & 38.8 & 32.7 & 27.0 & 23.0 \\
\hline & & Shade & 28.4 & 32.1 & 32.9 & 32.9 & 33.2 & 32.3 & 31.5 & 30.8 & 26.9 & 23.5 & 31.3 & 38.2 & 38.4 & 35.4 & 36.4 & 34.3 & 33.3 & 32.2 & 26.7 & 23.4 \\
\hline & \multirow[t]{2}{*}{ September } & Sun & 32.3 & 33.9 & 36.5 & 37.2 & 37.8 & 36.9 & 36.7 & 35.7 & 33.0 & 27.4 & 33.6 & 35.8 & 41.4 & 38.9 & 42.9 & 38.7 & 40.5 & 41.0 & 41.8 & 27.6 \\
\hline & & Shade & 29.6 & 31.9 & 34.2 & 37.4 & 35.1 & 33.8 & 34.9 & 32.7 & 30.8 & 27.7 & 34.9 & 37.3 & 42.1 & 40.3 & 35.9 & 38.8 & 35.1 & 32.9 & 27.9 & 26.1 \\
\hline \multirow[t]{6}{*}{ ICLF-3 } & \multirow[t]{2}{*}{ July } & Sun & 19.4 & 19.6 & 20.2 & 21.6 & 22.3 & 23.2 & 23.1 & 22.3 & 21.2 & 19.5 & 21.5 & 22.1 & 22.4 & 24.4 & 25.2 & 26.6 & 25.4 & 23.5 & 21.9 & 19.3 \\
\hline & & Shade & 19.4 & 19.7 & 20.2 & 21.7 & 22.4 & 23.3 & 23.3 & 22.4 & 21.2 & 19.6 & 21.0 & 21.8 & 21.9 & 24.0 & 24.6 & 25.8 & 25.3 & 23.6 & 21.6 & 19.3 \\
\hline & \multirow[t]{2}{*}{ August } & Sun & 32.3 & 36.1 & 35.3 & 37.2 & 37.5 & 35.4 & 33.8 & 31.0 & 25.5 & 22.6 & 37.9 & 40.4 & 41.2 & 41.7 & 42.0 & 40.4 & 37.6 & 37.0 & 27.6 & 22.9 \\
\hline & & Shade & 29.5 & 32.2 & 35.2 & 33.6 & 33.8 & 32.9 & 31.8 & 29.2 & 25.4 & 23.6 & 29.7 & 34.3 & 39.8 & 35.6 & 36.5 & 35.2 & 34.6 & 32.5 & 27.1 & 23.7 \\
\hline & \multirow[t]{2}{*}{ September } & Sun & 32.0 & 33.6 & 36.2 & 36.7 & 38.6 & 43.5 & 41.8 & 39.4 & 32.7 & 26.9 & 35.5 & 35.1 & 40.7 & 38.0 & 39.7 & 48.2 & 46.1 & 44.7 & 36.6 & 27.0 \\
\hline & & Shade & 29.9 & 32.6 & 34.6 & 35.8 & 36.2 & 34.6 & 34.7 & 33.1 & 30.5 & 27.2 & 34.0 & 35.8 & 40.1 & 40.5 & 36.0 & 35.7 & 34.2 & 31.9 & 27.1 & 25.3 \\
\hline
\end{tabular}


Table 2 Month average of relative humidity (RH, \%) and wind speed (Ws, m. $\mathrm{s}^{-1}$ ), in sun and shade, in integrated crop-livestock-forest systems containing eucalyptus (ICLF-1 and ICLF-2) and native trees (ICLF-3), in Campo Grande, MS, Brazil

\begin{tabular}{|c|c|c|c|c|c|c|c|c|c|c|c|c|c|c|c|c|c|c|c|c|c|c|}
\hline \multirow[t]{3}{*}{ Systems } & \multirow[t]{3}{*}{ Months } & \multirow[t]{3}{*}{ Place } & \multicolumn{10}{|c|}{$\mathrm{RH}(\%)$} & \multicolumn{10}{|c|}{ Ws $\left(m \cdot s^{-1}\right)$} \\
\hline & & & \multicolumn{10}{|c|}{ Hours } & \multicolumn{10}{|c|}{ Hours } \\
\hline & & & 8 & 9 & 10 & 11 & 12 & 1 & 2 & 3 & 4 & 5 & 8 & 9 & 10 & 11 & 12 & 1 & 2 & 3 & 4 & 5 \\
\hline \multirow[t]{6}{*}{ ICLF-1 } & \multirow[t]{2}{*}{ July } & Sun & 76.7 & 79.5 & 78.3 & 73.1 & 71.8 & 69.8 & 69.4 & 73.5 & 77.3 & 84.9 & 2.2 & 2.4 & 2.3 & 2.3 & 3.0 & 2.0 & 2.2 & 1.8 & 1.9 & 2.1 \\
\hline & & Shade & 80.6 & 82.1 & 80.4 & 75.7 & 73.8 & 72.7 & 71.8 & 74.6 & 78.0 & 84.0 & 2.5 & 2.0 & 2.8 & 1.4 & 3.1 & 2.4 & 2.8 & 2.8 & 2.6 & 2.3 \\
\hline & \multirow[t]{2}{*}{ August } & Sun & 30.1 & 26.9 & 24.5 & 22.6 & 23.0 & 24.0 & 24.5 & 34.6 & 51.7 & 60.0 & 1.3 & 0.7 & 1.0 & 0.7 & 0.4 & 0.0 & 0.1 & 0.5 & 0.6 & 0.0 \\
\hline & & Shade & 39.7 & 34.6 & 30.8 & 26.5 & 26.9 & 28.4 & 28.7 & 31.1 & 46.2 & 55.2 & 1.6 & 0.8 & 0.9 & 0.4 & 1.7 & 0.5 & 0.3 & 0.7 & 0.2 & 0.0 \\
\hline & \multirow[t]{2}{*}{ September } & Sun & 29.3 & 26.0 & 24.9 & 23.3 & 21.8 & 19.9 & 19.5 & 18.9 & 30.5 & 32.8 & 1.7 & 2.7 & 3.5 & 2.2 & 2.1 & 1.7 & 0.9 & 0.3 & 2.0 & 0.0 \\
\hline & & Shade & 33.7 & 28.3 & 27.1 & 26.2 & 26.2 & 23.7 & 25.2 & 23.2 & 29.8 & 26.9 & 2.4 & 4.8 & 3.7 & 3.8 & 3.2 & 2.5 & 1.4 & 1.2 & 1.4 & 0.0 \\
\hline \multirow[t]{6}{*}{ ICLF-2 } & \multirow[t]{2}{*}{ July } & Sun & 83.4 & 81.8 & 79.7 & 75.2 & 73.8 & 71.8 & 71.6 & 75.5 & 79.9 & 84.7 & 0.5 & 0.8 & 0.8 & 0.3 & 0.2 & 0.5 & 0.2 & 0.6 & 0.4 & 0.4 \\
\hline & & Shade & 83.5 & 82.1 & 79.9 & 75.5 & 74.5 & 72.9 & 72.2 & 75.7 & 79.6 & 84.9 & 0.4 & 0.5 & 0.8 & 0.6 & 0.5 & 0.2 & 0.3 & 0.7 & 0.3 & 0.2 \\
\hline & \multirow[t]{2}{*}{ August } & Sun & 37.4 & 30.8 & 24.8 & 23.7 & 21.4 & 23.4 & 24.7 & 29.2 & 36.5 & 52.1 & 1.1 & 0.0 & 0.2 & 0.0 & 1.0 & 0.6 & 0.2 & 0.0 & 0.0 & 0.0 \\
\hline & & Shade & 36.4 & 30.8 & 28.5 & 26.2 & 25.2 & 26.6 & 28.2 & 29.9 & 38.2 & 49.8 & 1.0 & 0.0 & 0.1 & 0.0 & 0.7 & 0.4 & 1.3 & 0.0 & 0.0 & 0.0 \\
\hline & \multirow[t]{2}{*}{ September } & Sun & 28.8 & 26.8 & 23.4 & 22.2 & 20.4 & 21.1 & 20.4 & 23.0 & 28.3 & 30.5 & 0.6 & 2.1 & 1.4 & 1.3 & 0.1 & 0.6 & 0.0 & 0.2 & 0.0 & 0.1 \\
\hline & & Shade & 31.6 & 30.0 & 26.0 & 21.9 & 23.2 & 24.5 & 23.3 & 24.2 & 29.4 & 30.5 & 0.7 & 2.1 & 1.3 & 1.9 & 0.9 & 0.0 & 0.0 & 0.4 & 0.3 & 0.0 \\
\hline \multirow[t]{6}{*}{ ICLF-3 } & \multirow[t]{2}{*}{ July } & Sun & 81.6 & 81.2 & 79.3 & 74.8 & 73.4 & 70.9 & 70.9 & 74.5 & 78.4 & 84.1 & 1.3 & 2.6 & 1.6 & 1.1 & 0.5 & 1.3 & 1.3 & 1.5 & 0.8 & 0.9 \\
\hline & & Shade & 81.8 & 81.8 & 80.2 & 75.3 & 73.5 & 71.4 & 71.1 & 74.4 & 79.1 & 84.5 & 1.2 & 1.6 & 2.2 & 1.6 & 0.6 & 0.9 & 1.2 & 1.3 & 1.2 & 0.8 \\
\hline & \multirow[t]{2}{*}{ August } & Sun & 31.7 & 25.5 & 23.8 & 20.6 & 21.0 & 22.4 & 24.3 & 29.5 & 42.0 & 48.5 & 0.9 & 0.3 & 0.1 & 0.4 & 0.3 & 1.0 & 0.3 & 0.0 & 0.0 & 0.0 \\
\hline & & Shade & 34.4 & 29.5 & 24.0 & 23.8 & 24.2 & 25.3 & 26.8 & 32.3 & 41.1 & 44.1 & 1.1 & 0.3 & 0.3 & 0.6 & 0.3 & 1.0 & 0.3 & 0.0 & 0.0 & 0.0 \\
\hline & \multirow[t]{2}{*}{ September } & Sun & 29.4 & 26.3 & 24.0 & 23.7 & 20.2 & 15.2 & 16.5 & 16.8 & 26.0 & 28.9 & 1.1 & 2.5 & 2.2 & 1.3 & 2.2 & 0.5 & 0.2 & 0.9 & 0.2 & 0.0 \\
\hline & & Shade & 32.7 & 27.5 & 25.8 & 24.3 & 22.2 & 22.0 & 22.8 & 22.4 & 29.4 & 29.8 & 1.2 & 2.8 & 2.5 & 2.0 & 1.3 & 1.0 & 0.5 & 0.6 & 0.5 & 0.0 \\
\hline
\end{tabular}

Baêta and Souza (2010), environments with relative humidity between 60 and $70 \%$ are considered as comfortable. However, high humidity combined with high temperatures, heat loss by sweating processes become inefficient, therefore, the animal requires more energy expenditure for thermoregulation. The wind speed varied widely throughout the day and between systems (Table 2), but they were always greater in the system with scattered native trees (ICLF-3), easing the heat sensation imposed by higher air temperatures during the study period. With the exception of September, the values found themselves within the limits considered comfortable (from 1.38 to $2.22 \mathrm{~m} \mathrm{~s}^{-1}$ ) by Baêta and Souza (2010).

Significant quadratic responses $(P<0.05)$ were observed for air temperature and wet bulb temperature depending on the time and sampling, in sun and shade conditions (Table 3). In all evaluated periods, the highest averages were those obtained in the sun, with considerable reductions in the shade. The maximum values of air temperature and wet bulb temperature registered in the shade were 32.0 and $23.2^{\circ} \mathrm{C}$, respectively, at 12:00 p.m. The results were possibly influenced by the high insolation during the evaluation period.

Significant quadratic responses $(P<0.05)$ were found for black globe temperature depending on the system and local conditions (Table 4). The highest averages were obtained in the sun, influenced by the high incidence of solar radiation in the evaluated systems. In shade, the largest recorded estimates were $34.3{ }^{\circ} \mathrm{C}$ for both systems with eucalyptus dense (ICLF1) and less dense (ICLF-2) and $33.2{ }^{\circ} \mathrm{C}$ for the system with scattered native trees (ICLF-3), at 12:00 p.m.

\section{Thermal comfort indexes}

The benefits of shading on the Temperature and Humidity Index can be observed in Table 5, with significant quadratic responses $(P<0.05)$ for systems and local conditions according to time. The highest environmental thermal condition was at 12:00 p.m., with maximum values in the sun for the system with dense eucalyptus (80, ICLF-1), followed by system with less dense eucalyptus (81, ICLF-2), and system with scattered native trees (81, ICLF-3) and considerable reductions in the shade in the systems with different arrangement of eucalyptus (78, ICLF-1 and 79, ICLF-2) and scattered native trees (78, ICLF-3), which obtained the best thermal comfort condition in shade at all times.

The Black Globe Temperature and Humidity Index showed significant quadratic response $(P<0.05)$ depending on time for system and location (Table 5). The best comfort conditions evaluated by index were obtained in shade (79) for scattered native trees (ICLF-3), and 81 for different arrangement of eucalyptus (ICLF-1 and ICLF -2) and the higher ones were obtained in sun (88 in ICLF-3; 85 in ICLF- 2 and 83 in ICLF- 
Table 3 Air temperature $\left(\mathrm{Ta},{ }^{\circ} \mathrm{C}\right)$ and wet bulb temperature ( $\mathrm{Tbw}$, ${ }^{\circ} \mathrm{C}$ ), in sun and shade, from 8:00 a.m. to 5:00 p.m. (local time, GMT-4:00), in integrated croplivestock-forest systems, in Campo Grande, MS, Brazil

\begin{tabular}{|c|c|c|c|c|c|c|c|c|c|c|c|c|}
\hline \multirow[t]{2}{*}{ Variables } & \multirow[t]{2}{*}{ Place } & \multicolumn{10}{|c|}{ Hours } & \multirow[t]{2}{*}{$R^{2}$} \\
\hline & & 8 & 9 & 10 & 11 & 12 & 1 & 2 & 3 & 4 & 5 & \\
\hline \multirow[t]{2}{*}{$\mathrm{Ta}\left({ }^{\circ} \mathrm{C}\right)$} & Sun & 28.4 & 30.9 & 32.7 & 33.8 & 34.1 & 33.6 & 32.4 & 30.4 & 27.7 & 24.2 & 0.98 \\
\hline & Shade & 27.4 & 29.4 & 30.8 & 31.7 & 32.0 & 31.7 & 30.8 & 29.3 & 27.3 & 24.7 & 0.99 \\
\hline \multirow[t]{2}{*}{ Tbw $\left({ }^{\circ} \mathrm{C}\right)$} & Sun & 20.6 & 22.6 & 24.0 & 24.9 & 25.1 & 24.8 & 23.9 & 22.5 & 20.4 & 17.8 & 0.98 \\
\hline & Shade & 19.8 & 21.3 & 22.3 & 23.0 & 23.2 & 23.0 & 22.4 & 21.3 & 19.9 & 18.0 & 0.99 \\
\hline
\end{tabular}

1), always at 12:00 p.m., with noticeable reduction in the evening, as expected.

The variations observed in air temperature, black globe temperature, and wind speed (Tables 1, 2, 3, and 4) throughout the experimental period significantly influenced the Radiant Thermal Load with significant quadratic responses $(P<0.05)$. The highest Radiant Thermal Load values were found at 12:00 p.m. on every month, system, and location (Table 6). The Radiant Thermal Load variation between systems was 422 to $654 \mathrm{~W} \mathrm{~m}^{-2}$ in July, from 423 to $660 \mathrm{~W} \mathrm{~m}^{-2}$ in August, and 446 to $794 \mathrm{~W} \mathrm{~m}^{-2}$ in September. The Radiant Thermal Load is closely related to heat exchange by radiation between animals and environment, so in tropical regions, the lowest possible values of Radiant Thermal Load are desirable (Silva 2000). In this work, the Radiant Thermal Load was consistently high throughout the experimental period. This result underscores the relevance of environmental management in order to protect the animals against direct solar radiation so they are able to better withstand these climatic peculiarities (Morais et al. 2008). In this case, all the systems' trees were able to reduce the Radiant Thermal Load in the shade, in every month.

\section{Discussion}

It should be noted that, even in the winter season in the Southern hemisphere, between July and September, the air temperatures recorded in the sun were superior to that considered critical $\left(35^{\circ} \mathrm{C}\right)$ by Baêta and Souza (2010) for Zebu, with peaks of $43.5^{\circ} \mathrm{C}$ at 1:00 p.m. in September. Moore et al. (2012) warn that high levels of air temperature, solar radiation, and humidity provide an uncomfortable thermal environment, demanding compensation systems from the animals to maintain homeothermy, even from more adapted ones. Even though such mechanisms are efficient, they impose an energy cost and, therefore, a fall in productivity (Mader et al. 2010). In this sense, shades in adequate amounts serve as protection against thermal radiation because they reduce the heat load associated with solar radiation (Schütz et al. 2010).

In this study, the approach of the spring equinox and the increased photoperiod were possibly responsible for the higher values of microclimate variables in September. In this case, one notes the importance of the tree component in improving the microclimate in tropical pastures considering the values of air temperatures in the shade, in all production systems, with $8.9{ }^{\circ} \mathrm{C}$ for scattered native trees (ICLF-3) at 1:00 p.m., $5.7^{\circ} \mathrm{C}$ for dense eucalyptus (ICLF-1) at 1:00 p.m., and $2.7^{\circ} \mathrm{C}$ for less dense eucalyptus (ICLF-2) at 12:00 p.m., lower than in the sun, in this case, in the shade of scattered native trees (ICLF-3), at 1:00 p.m., the air temperature was $20.4 \%$ lower than in the sun, consequently, the black globe temperature also decreased by $26.0 \%$ compared to the sun (Table 1 ). In the shadow, in September, there was also an increase of 4.5, 3.9 , and $1.4 \%$ in the relative humidity of the air in, ICLF-3, ICLF-1, and ICLF-2 systems, respectively (Table 2). It should be noted the importance of spacing between trees and rows to allow heat exchange in the understory. In this study, the highest wind speed was measured in scattered native trees

Table 4 Black globe temperatures $\left(\mathrm{Tbg},{ }^{\circ} \mathrm{C}\right)$, in sun and shade, in integrated crop-livestock-forest systems containing eucalyptus (ICLF-1 and ICLF-2) and native trees (ICLF-3), from 8:00 a.m. to 5:00 p.m. (local time, GMT-04:00), in Campo Grande, MS, Brazil

\begin{tabular}{|c|c|c|c|c|c|c|c|c|c|c|c|c|c|}
\hline \multirow[t]{2}{*}{ Variable } & \multirow[t]{2}{*}{ Systems } & \multirow[t]{2}{*}{ Place } & \multicolumn{10}{|c|}{ Hours } & \multirow[t]{2}{*}{$R^{2}$} \\
\hline & & & 8 & 9 & 10 & 11 & 12 & 1 & 2 & 3 & 4 & 5 & \\
\hline \multirow[t]{6}{*}{$\operatorname{Tbg}\left({ }^{\circ} \mathrm{C}\right)$} & \multirow[t]{2}{*}{ ICLF-1 } & Sun & 28.0 & 31.7 & 34.4 & 36.1 & 36.7 & 36.4 & 35.0 & 32.7 & 29.4 & 25.0 & 0.97 \\
\hline & & Shade & 29.0 & 31.4 & 33.1 & 34.1 & 34.3 & 33.9 & 32.7 & 30.8 & 28.2 & 24.8 & 0.99 \\
\hline & \multirow[t]{2}{*}{ ICLF-2 } & Sun & 30.3 & 33.9 & 36.5 & 38.1 & 38.6 & 38.0 & 36.3 & 33.6 & 29.9 & 25.1 & 0.95 \\
\hline & & Shade & 28.9 & 31.4 & 33.1 & 34.1 & 34.3 & 33.8 & 32.6 & 30.6 & 27.8 & 24.3 & 0.98 \\
\hline & \multirow[t]{2}{*}{ ICLF-3 } & Sun & 33.0 & 36.9 & 39.6 & 41.1 & 41.4 & 40.4 & 38.2 & 34.8 & 30.1 & 24.2 & 0.96 \\
\hline & & Shade & 27.8 & 30.2 & 31.8 & 32.8 & 33.2 & 32.8 & 31.8 & 30.1 & 27.7 & 24.6 & 0.95 \\
\hline
\end{tabular}


Table. 5 Temperature and Humidity Index (THI) and Black Globe Temperature and Humidity Index (BGHI), in sun and shade, in integrated crop-livestock-forest systems containing eucalyptus (ICLF-1 and ICLF-2) and native trees (ICLF-3), from 8:00 a.m. to 5:00 p.m. (local time, GMT-4:00), in Campo Grande, MS, Brazil

\begin{tabular}{|c|c|c|c|c|c|c|c|c|c|c|c|c|}
\hline \multirow[t]{2}{*}{ System } & \multirow[t]{2}{*}{ Place } & \multicolumn{10}{|c|}{ Hour } & \multirow[t]{2}{*}{$R^{2}$} \\
\hline & & 8 & 9 & 10 & 11 & 12 & 1 & 2 & 3 & 4 & 5 & \\
\hline \multicolumn{13}{|c|}{ Temperature and Humidity Index (THI) } \\
\hline \multirow[t]{2}{*}{ ICLF-1 } & Sun & 74 & 76 & 78 & 79 & 80 & 79 & 78 & 77 & 74 & 71 & 0.98 \\
\hline & Shade & 74 & 76 & 77 & 78 & 78 & 78 & 77 & 76 & 74 & 71 & 0.99 \\
\hline \multirow[t]{2}{*}{ ICLF-2 } & Sun & 75 & 78 & 79 & 80 & 81 & 80 & 79 & 77 & 74 & 70 & 0.98 \\
\hline & Shade & 74 & 76 & 78 & 78 & 79 & 78 & 77 & 76 & 73 & 71 & 0.99 \\
\hline \multirow[t]{2}{*}{ ICLF-3 } & Sun & 76 & 78 & 80 & 81 & 81 & 80 & 79 & 77 & 73 & 70 & 0.98 \\
\hline & Shade & 73 & 75 & 77 & 77 & 78 & 78 & 77 & 75 & 73 & 71 & 0.96 \\
\hline \multicolumn{13}{|c|}{ Black Globe Temperature and Humidity Index (BGHI) } \\
\hline \multirow[t]{2}{*}{ ICLF-1 } & Sun & 74 & 78 & 81 & 82 & 83 & 83 & 81 & 79 & 76 & 71 & 0.97 \\
\hline & Shade & 75 & 78 & 79 & 80 & 81 & 80 & 79 & 77 & 74 & 71 & 0.99 \\
\hline \multirow[t]{2}{*}{ ICLF-2 } & Sun & 77 & 80 & 83 & 84 & 85 & 84 & 83 & 80 & 76 & 71 & 0.95 \\
\hline & Shade & 75 & 78 & 79 & 80 & 81 & 80 & 79 & 77 & 74 & 70 & 0.98 \\
\hline \multirow[t]{2}{*}{ ICLF-3 } & Sun & 80 & 84 & 86 & 88 & 88 & 87 & 85 & 81 & 76 & 70 & 0.97 \\
\hline & Shade & 74 & 77 & 78 & 79 & 79 & 79 & 78 & 76 & 74 & 71 & 0.95 \\
\hline
\end{tabular}

system (ICLF-3), followed by less dense eucalyptus system (ICLF-2). Although this study did not focus on the direct assessment of animals, the low density of trees in the systems would probably favor thermal exchanges by conduction and convection between them and the environment, reducing the thermal stress resulting from the recorded high temperatures (Baêta and Souza 2010).

As expected and observed in this study, the differences and respective efficiencies of tree species in altering the microclimate are due to the canopies' structure and format: the dense and larger the canopies and the lower the heat load associated with solar radiation in the systems. Thus, the round shape of the canopies of scattered native trees (Cambará and Cumbaru, ICLF-3 system) made it possible to reduce approximately $20 \%$ of the black globe temperature in the shade compared to the sun $\left(41.4{ }^{\circ} \mathrm{C}\right.$ ), while the eucalyptus (ICLF-1 and ICLF-2 systems) reduced less $(7.1 \%$ and $11.1 \%)$, to according Table 4. In the case of the eucalyptus, its ellipsoidal shape, with spaced branches, facilitates the solar incidence on the surface of the soil, with less radiation-blocking and increased energy flow. Indeed, according to Schumacher and Poggiani (1993), the incident sunlight in areas with eucalyptus is greatly reduced, but slightly changed qualitatively, reaching the forest canopy and being reflected back to the environment. In broadleaf trees such as Cambará and Cumbaru (ICLF-3), however, the light undergoes selective absorption, modifying its use and even the photosynthetic processes. Interestingly, the tree component is able to also modify the environment near the tree beyond the shaded area (Abreu and Labaki 2010).

When evaluating pine trees (Pinus taeda L.) in open sky and in $15 \times 3$ and $9 \times 3 \mathrm{~m}$ spacing, in Parana (Brazil), a region of sub-tropical climate, Soares et al. (2009) obtained similar
Table. 6 Radiant Thermal Load (RTL), in July, August, and September, in sun and shade, in integrated crop-livestock-forest systems containing eucalyptus (ICLF-1 and ICLF-2) and native trees (ICLF-3), from 8:00 a.m. to 5:00 p.m. (local time, GMT04:00), in Campo Grande, MS, Brazil

\begin{tabular}{|c|c|c|c|c|c|c|c|c|c|c|c|c|}
\hline \multicolumn{13}{|c|}{ Radiant Thermal Load $\left(\mathrm{W} \mathrm{m}^{-2}\right)$} \\
\hline \multicolumn{13}{|l|}{ July } \\
\hline \multirow[t]{2}{*}{ System } & Place & Hour & & & & & & & & & & $R^{2}$ \\
\hline & & 8 & 9 & 10 & 11 & 12 & 1 & 2 & 3 & 4 & 5 & \\
\hline \multirow[t]{2}{*}{ ICLF-1 } & Sun & 508 & 544 & 572 & 590 & 599 & 599 & 590 & 571 & 544 & 507 & 0.92 \\
\hline & Shade & 440 & 464 & 481 & 492 & 498 & 497 & 490 & 477 & 458 & 433 & 0.92 \\
\hline \multirow[t]{2}{*}{ ICLF-2 } & Sun & 463 & 517 & 556 & 581 & 591 & 586 & 567 & 533 & 485 & 422 & 0.92 \\
\hline & Shade & 448 & 470 & 486 & 497 & 501 & 499 & 492 & 478 & 459 & 433 & 0.96 \\
\hline \multirow[t]{2}{*}{ ICLF-3 } & Sun & 478 & 550 & 603 & 638 & 654 & 651 & 630 & 590 & 531 & 454 & 0.85 \\
\hline & Shade & 442 & 464 & 480 & 491 & 497 & 497 & 491 & 480 & 464 & 442 & 0.88 \\
\hline \multicolumn{13}{|l|}{ August } \\
\hline \multirow[t]{2}{*}{ System } & Place & Hour & & & & & & & & & & $R^{2}$ \\
\hline & & 8 & 9 & 10 & 11 & 12 & 1 & 2 & 3 & 4 & 5 & \\
\hline \multirow[t]{2}{*}{ ICLF-1 } & Sun & 477 & 525 & 559 & 580 & 588 & 582 & 562 & 530 & 483 & 424 & 0.9 \\
\hline & Shade & 525 & 546 & 559 & 564 & 561 & 550 & 531 & 504 & 470 & 427 & 0.97 \\
\hline \multirow[t]{2}{*}{ ICLF-2 } & Sun & 525 & 554 & 574 & 584 & 585 & 576 & 558 & 530 & 492 & 445 & 0.89 \\
\hline & Shade & 494 & 522 & 541 & 551 & 554 & 547 & 533 & 510 & 479 & 439 & 0.99 \\
\hline \multirow[t]{2}{*}{ ICLF-3 } & Sun & 593 & 628 & 651 & 660 & 657 & 640 & 611 & 569 & 513 & 445 & 0.91 \\
\hline & Shade & 509 & 532 & 546 & 552 & 551 & 541 & 524 & 498 & 465 & 423 & 0.95 \\
\hline \multicolumn{13}{|c|}{ September } \\
\hline \multirow[t]{2}{*}{ System } & Place & Hour & & & & & & & & & & $R^{2}$ \\
\hline & & 8 & 9 & 10 & 11 & 12 & 1 & 2 & 3 & 4 & 5 & \\
\hline \multirow[t]{2}{*}{ ICLF-1 } & Sun & 538 & 573 & 598 & 612 & 616 & 609 & 592 & 565 & 527 & 479 & 0.77 \\
\hline & Shade & 524 & 546 & 561 & 569 & 570 & 564 & 551 & 531 & 504 & 471 & 0.85 \\
\hline \multirow[t]{2}{*}{ ICLF-2 } & Sun & 572 & 602 & 623 & 634 & 635 & 627 & 609 & 581 & 543 & 496 & 0.56 \\
\hline & Shade & 545 & 564 & 576 & 580 & 577 & 566 & 547 & 521 & 488 & 446 & 0.74 \\
\hline \multirow[t]{2}{*}{ ICLF-3 } & Sun & 703 & 753 & 783 & 794 & 784 & 755 & 706 & 637 & 548 & 439 & 0.97 \\
\hline & Shade & 515 & 537 & 551 & 559 & 560 & 554 & 542 & 523 & 498 & 465 & 0.91 \\
\hline
\end{tabular}


results to those of this study, in which planting fields with fewer trees showed reductions in air temperature values (an average of $21.6{ }^{\circ} \mathrm{C}$ ). According to the authors, a higher density of trees hinders the wind movement. Silva et al. (2010) registered lower air temperature $\left(26.7^{\circ} \mathrm{C}\right)$ and wet bulb temperature $\left(21.3^{\circ} \mathrm{C}\right)$ under the shade of Acacia holosericea, with a $13.6 \%$ increment in the sun for air temperature $\left(30.9^{\circ} \mathrm{C}\right)$ and $3.2 \%$ for wet bulb temperature $\left(22.0^{\circ} \mathrm{C}\right)$, corroborating the fact that these trees are able to intercept part of the solar radiation. In this study, from 12:00 a.m. to 1:00 p.m. in the sun, there was an increase of air temperature $(6.1 \%)$ and wet bulb temperature $(7.6 \%)$, to according Table 3 .

Ferreira et al. (2011a) found similar results in silvopastoral systems in northern Rio de Janeiro (southeastern Brazil) with Santa Ines sheep, where the black globe temperature was $13.2 \%$ lower in the shade $\left(32.9^{\circ} \mathrm{C}\right.$ vs $\left.37.9^{\circ} \mathrm{C}\right)$. More comfortable temperature conditions directly benefit the animals. In this regard, Ferreira et al. (2006) determined the physiological parameters of crossbred cattle subjected to heat stress and observed conditions of comfort and severe heat stress when black globe temperature was 23 and $44{ }^{\circ} \mathrm{C}$, respectively.

For animal thermal comfort, Baêta and Souza (2010) found that Temperature and Humidity Index values lower than or equal to 70 indicated non-stressful environments; between 71 and 78 were considered critical; 79 to 83 indicated a dangerous condition; and above 83 , an emergency one. According to Table 5, the Temperature and Humidity Index obtained ranged from critical to dangerous, directly influenced by high air temperature and wet bulb temperature checked in the experimental period (Tables 1 and 3). However, at 12.00 a.m., the scattered native trees system (ICLF-3) was able to mitigate the heat, decreasing in $3.7 \%$ the Temperature and Humidity Index (Table 5), followed by less dense eucalyptus system (ICLF-2) and the dense eucalyptus system (ICLF-1) with increase of $2.5 \%$.

Other Brazilian authors also found quite alarming situations for pasture-bred cattle in tropical regions. In pastures in the state of Paraná, with different conditions of natural shading, Navarini et al. (2009) determined Temperature and Humidity Index values similar to those found in this study, from January to February (summer), in small groves of Guajuvira (76) and in full sun (80), but at 3:00 p.m. Evaluating native species as wilco (Anadenanthera colubrine Vell.), rose pepper tree (Schinus terebinthifolius), Brazilian copal (Hymenaea courbaril L.), ipe tree (Tabebuia alba Cham.), and cumbaru (Dipteryx alata Vog.) dispersed in pastures in the month of May (autumn), Ferreira et al. (2011b) determined average values of Temperature and Humidity Index between 74 and 78 in the shade, and 82 in full sun.

For the Black Globe and Humidity Index, the shade of scattered native trees (ICLF-3) was the one with the best conditions for thermal comfort, with a reduction of $10.2 \%$, followed by the less dense eucalyptus system (ICLF-2), with
$4.7 \%$, and dense eucalyptus system (ICLF-1), with $2.4 \%$, at 12:00 a.m. (Table 5). However, despite the reduction of Black Globe and Humidity Index values in the shade, the environments were still in thermal discomfort for cattle, since they were classified as ranging from hazardous to emergency conditions, according to Baeta (1985). When assessing the shadow of unspecified native trees in pastures of the southeast region of the country. Ablas et al. (2007) found Black Globe and Humidity Index values of 87 and 89 in shade and sun, respectively. Souza et al. (2007) achieved extremely high Black Globe and Humidity Index values in sun (98) and in shade (88), indicating heat stress for Sindhi cattle in the semiarid region of the state of Paraíba, Brazil.

According to Silva (2006), the presence of trees in pastures directly affects the energy balance of a system and thus they can intercept up to $80 \%$ of incident radiation, corresponding to a reduction of up to $30 \%$ in the Radiant Thermal Load. In fact, in this study, at 12:00 p.m. to 1:00 p.m., the scattered native trees (ICLF-3) provided a $24.0 \%$ reduction in Radiant Thermal Load in July, $16.3 \%$ in August, and $29.6 \%$ in September. Of all densities, the less dense eucalyptus system (ICLF-2) proved to be more efficient reducing the Radiant Thermal Load in $15.2 \%$ in July, $5.3 \%$ in August, and $8.5 \%$ in September compared to dense eucalyptus system (ICLF-1), with $17.0 \%$ in July, $4.6 \%$ in August, and $7.5 \%$ in September (Table 6). In the state of Paraná, Baliscei et al. (2013) found, at 12:00 p.m., average Radiant Thermal Load values of $639.8 \mathrm{~W} \mathrm{~m}^{-2}$ in the silvopastoral system and $778.4 \mathrm{~W} \mathrm{~m}^{-2}$ in the unshaded treatment, corresponding to a reduction of $17.8 \%$ of the incident thermal load in the system. In Pernambuco, Souza et al. (2010) found similar results, with a maximum value of $763.5 \mathrm{~W} \mathrm{~m}^{-2}$ at 1:00 p.m. in the sun and $530.2 \mathrm{~W} \mathrm{~m}^{-2}$ at 2:00 p.m. in the shade, reinforcing the importance of shading in the reduction of the Radiant Thermal Load on animals. When assessing the shadow quality given by white cedar (Melia azedarach L.), white leadtree (Leucaena leucocephala Lam.), sun Bengal almond (Terminalia catappa L.), and bamboo (Bambusa vulgaris SCH.) in pastures in Piracicaba, Brazil, Guiselini et al. (1999) also found lower radiant thermal load in the shade $\left(546.7 \mathrm{~W} \mathrm{~m}^{-2}\right.$ at 2:00 p.m.).

Although the calculated thermal comfort indexes still demonstrate possible discomfort for animals raised in tropical pastures, it is observed that the presence of trees is paramount to the improvement of a productive thermal environment, especially when dispersed or in lower density.

\section{Conclusion}

The integrated crop-livestock-forest systems promoted beneficial microclimate changes to the grazing animals, in the Brazilian Midwest. The systems with less dense eucalyptus (ICLF-2) and scattered native trees (ICLF-3) provided better 
thermal comfort condition in relation to the dense eucalyptus system (ICLF-1). The highest spacing between rows of trees and in lower density, allowed better circulation of winds, reduction in air temperature and black globe temperature, and increase in relative humidity in the shade, favoring animal welfare. Therefore, it is observed that with the presence of trees in pastures, there were possible reductions of up to $3.7 \%$ in Temperature and Humidity Index, $10.2 \%$ in the Black Globe Temperature and Humidity Index and $28.3 \%$ of the Radiant Thermal Load in the shade in relation to areas of full sun.

\section{References}

Ablas DS, Titto EAL, Pereira AMF, Titto CG, Leme TMC (2007) Comportamento de bubalinos a pasto frente a disponibilidade de sombra e água Para imersão. Cienc Anim Bras 8:167-175

Abreu LV, Labaki LC (2010) Conforto térmico propiciado por algumas espécies arbóreas: avaliação do raio de influência através de diferentes índices de conforto. Rev ANTAC 10:103-117

Aggarwal A, Upadhyay R (2013) Heat stress and animal productivity. Springer, London doi:10.1007/978-81-322-0879-2 1.

Baêta FC (1985) Responses of lactating dairy cows to the combined effects of tempertature, humidity and wind velocity in the warm season. 218 f. Thesis (Doctorate in Ambience Animal)Agricultural Engeneering Department, University of Missouri, Columbia.

Baêta FC, Souza CF (2010) Ambiência em edificações rurais: conforto animal, 2nd edn. UFV, Viçosa

Baliscei MA, Barbosa OR, Souza W, Costa MAT, Fkutzmann, Queiroz EO (2013) Microclimate without shade and silvopastoral system during summer and winter. Acta Scient Anim Sci. doi:10.4025/ actascianimsci.v35i1.15155

Broom DM, Galindo FA, Murgueitio E (2013) Sustainable, efficient livestock production with high biodiversity and good welfare for animals. Proc Biol Sci 280:2013-2025

Buffington DE, Collazo Arocho A, Canton GH, Pitt D (1981) Black globe humidity index (BGHI) as a comfort equation for dairy cows. Trans ASAE 24:711-714. doi:10.13031/2013.34325

Esmay ML (1979) Principles of animal environment. AviPublishing, Porto Oeste

Ferreira F, Pires MFA, Martinez ML, Coelho SG, Carvalho AU, Ferreira PM, Facury Filho EJ, Campos WE (2006) Parâmetros fisiológicos de bovinos cruzados submetidos ao estresse calórico. Arq Bras Med Vet Zootec 58:732-773. doi:10.1590/S0102-09352006000500005

Ferreira RA, Estrada LHC, Thiébaut JTL, Granados LBC, Souza Júnior VR (2011a) Avaliação do comportamento de ovinos Santa Inês em sistema silvipastoril no norte fluminense. Cienc Agrotec 35:399 403. doi:10.1590/S1413-70542011000200023

Ferreira LCB, Machado Filho LCP, Hoetzel MJ, Labarrêre JG (2011b) O efeito de diferentes disponibilidades de sombreamento na dispersão de fezes dos bovinos nas pastagens. Rev Bras Agroec 6:137-146

Guiselini C, Silva IJO, Piedade SM (1999) Avaliação da qualidade do sombreamento arbóreo no meio rural. Rev Bras Eng Agric Ambiental 3:380-384
Gurgel EM, Seraphim OJ, Silva IJO (2012) Métodos de avaliação bioclimática da qualidade da sombra de árvores visando ao conforto térmico animal. Rev Energ Agric 2:20-34

Instituto Brasileiro de Geografia e Estatística (2015). Estatística de produção pecuária. $\mathrm{p} 80$

Köppen W (1948) Climatologia: con um estúdio de lós climas de la tierra. Fondo de Cultura Econômica, México, p. p 479

Mader TL, Johnson LJ, Gaughan JB (2010) A comprehensive index for assessing environmental stress in animals. J Anim Sci 88:21532165. doi:10.2527/jas.2009-2586

Moore DA, Duprau JL, Wenz JR (2012) Short communication: effects of dairy calf hutch elevation on heat reduction, carbon dioxide concentration, air circulation, and respiratory rates. J Dairy Sci 95:4050-4054

Morais DAEF, Maia ASC, Silva RG, Vasconcelos AM, Lima PO, Guilhermino MM (2008) Variação anual de hormônios tireoideanos e características termorreguladoras de vacas leiteiras em ambiente quente. R Bras Zootec 37(3):538-545

Navarini FC, Klosowski ES, Campos AT, Teixeira RA, Almeida CP (2009) Conforto térmico de bovinos da raça nelore a pasto sob diferentes condições de sombreamento e a pleno sol. Eng Agric 29:508-517

SAS INSTITUTE INC. STATISTICAL (2002) Analysis system user's guide. Version 9.0. Statistical Analysis System Institute, Cary, p. 1025

Schumacher MV, Poggiani F (1993) Caracterização microclimática no interior dos talhões de Eucalyptus camaldulensis Dehnh, Eucalyptus grandis hill ex maiden e Eucalyptus torelliana F. Muell, localizados em Anhembi, SP. Rev Cienc Florest 3:9-20

Schütz KE, Rogers AR, Poulouin YA, Cox NR, Tucker CB (2010) The amount of shade influences the behavior and physiology of dairy cattle. J Dairy Sci 93:125-133. doi:10.3168/jds.2009-2416

Silva RG (2000) Introdução à bioclimatologia animal. Nobel, São Paulo 450

Silva RG (2006) Predição da configuração de sombra de árvores em pastagens Para bovinos. Eng Agric 26:268-281

Silva RG, Maia ASC (2013) The environment. In: Silva RG, Maia ASC (ed) Principles of animal biometeorology. Springer, London, pp 137. doi:10.1007/978-94-007-5733-2.

Silva LC, Lucas FT, Borges BMMN, Silva WJ (2010) Influência da radiação fotossinteticamente ativa no crescimento e desenvolvimento de forrageiras tropicais. FAZU Rev 7:63-67

Soares AB, Sartor LR, Adami PF, Varela AC, Fonseca L, Mezzalira JC (2009) Influência da luminosidade no comportamento de onze espécies forrageiras perenes de verão. Rev Bras Zootec 38:443-451

Souza CF, Tinôco IFF, Baêta FC, Ferreira WPM, Silva RS (2002) Avaliação de materiais alternativos Para confecção do termômetro de globo. Ciênc Agrotec 26:157-164

Souza BB, Silva RMN, Marinho ML, Silva GA, Silva EMN, Souza AP (2007) Parâmetros fisiológicos e índice de tolerância ao calor de bovinos da raça Sindi no semi-árido Paraibano. Ciênc Agrotec 31: 883-888

Souza BB, Silva IJO, Mellace EM, Santos RFS, Zotti CA, Garcia PR (2010) Avaliação do ambiente físico promovido pelo sombreamento sobre o processo termorregulatório em novilhas leiteiras. ACSA 6: $59-65$

Thom EC (1958) Cooling degrees: day air-conditioning, heating and ventilating. Trans Am Soc Heat, Refrig Air Cond Eng 55:65-72

Tripon I, Cziszter LT, Bura M, Sossidou EM (2014) Effects of seasonal and climate variations on calves thermal comfort and behavior. Int $\mathrm{J}$ Biometeorol 58:1471-1478. doi:10.1007/s00484-013-0749-5

Trumbo BA, Wise LM, Hudy M (2012) Influence of protective shielding devices on recorded air temperature accuracy for a rugged outdoor thermal sensor used in climate change modeling. J Nat Env Sci 3:42-50 